\section{On editorials}

\author{
Philip Wiffen ${ }^{\odot}$
}

Editorials are a traditional part of most scientific journals proving an opportunity to comment on important findings, current events or an included paper worthy of discussion. Occasionally, an editorial will put research findings into perspective such as where they may be news worthy or unexpected. Other editorials may focus on some topical viewpoint that is seen to be important for hospital pharmacists.

There seems to have been an unspoken tradition that the editor-in-chief writes the vast majority of the editorials in EJHP and I inherited the task from my predecessor. That task is not onerous and is often enjoyable as it gives an opportunity to express a view or highlight an issue.

In recent months, a number of original articles submitted to EJHP have in my

Pain Research Unit, Churchill Hospital, Oxford, UK

Correspondence to Philip Wiffen, Pain Research Unit, Churchill Hospital, Oxford OX3 7LE, UK; pwiffen@ oxfordsrs.org.uk view been more suitably repurposed as an editorial and I have invited authors to consider that as an option. This will bring EJHP in line with other journals that either commission or accept editorials and should bring a wide perspective of views. That said, the editor-in-chief and the editorial board will retain the final say on whether an editorial is published or not.

So what is their purpose? There are four things that I consider important though not all four may feature in every piece. Editorials should inform, influence, educate and entertain. They can be a personal view and may be controversial with careful use of words and phrases. As opinion pieces, they may not always be balanced.

Editorials express the view of the writers and they represent the views of the authors alone. They do not represent the views of the editor-in-chief, the journal, EAHP or the publisher.
Editorials do not require an abstract, but a declaration of interests is required and submissions may be sent for peer review. A limited number of references may be used. Ideally, we need a word count of around 750 to 1500 words, but there is a measure of flexibility on the count.

In this issue, we publish an editorial from Hans Buiter and colleagues titled 'Cladribine repurposed in Multiple Sclerosis, making a fortune out of a generic drug'. The letters section of this journal is open for any who wish to comment on the views expressed.

Funding The author has not declared a specific grant for this research from any funding agency in the public, commercial or not-for-profit sectors.

Competing interests None declared.

Provenance and peer review Commissioned; internally peer reviewed.

(c) European Association of Hospital Pharmacists 2019. No commercial re-use. See rights and permissions. Published by BMJ.

$$
\text { D Check for updates }
$$

To cite Wiffen P. Eur J Hosp Pharm 2019;26:245.

Eur J Hosp Pharm 2019;26:245.

doi:10.1136/ejhpharm-2019-002064 